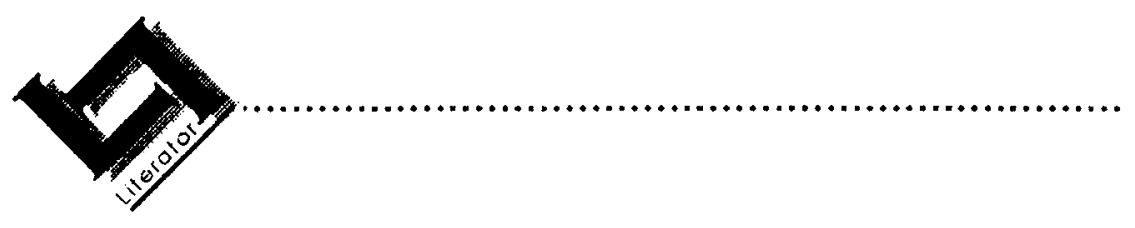

\title{
Opleiding in skeppende skryfwerk: Die skryfskool aan die Instituut vir Voortgesette Opleiding van UNISA (1985-1993)
}

Johann Lodewyk Marais

\section{Inleiding}

Vandag is dit in Afrikaans nie meer uitsonderlik om by opleiding in skeppende skryfwerk betrokke te wees nie. Menige skrywer, letterkundige of uitgewer is reeds op een of ander manier daarby betrokke, hetsy as student of kursusganger, of as aanbieder.

Reeds as leerling aan die Sekondêre Skool Harrismith het ek 'n belangstelling in die letterkunde ontwikkel, wat veral deur die werk van die Sestigers gestimuleer is. In standerd 9 het ek opstelle begin skryf wat aandag getrek en waarvan die inhoud my Afrikaans-onderwyser, C.J.H. Steenekamp, meermale ontstel het. Die konfrontasie tussen onderwyser en leerling het egter tot ' $n$ kritiese ingesteldheid teenoor die letterkunde gelei, wat later 'n groot wins blyk te gewees het. Uit hierdie tyd dateer ook my eerste gedigte.

Tydens my studentedae aan die Universiteit van Pretoria is geen formele opleiding in skeppende skryfwerk aangebied nie, alhoewel sommige dosente in die Departement Afrikaans, soos Elize Botha, Réna Pretorius en P.H. Roodt, by individuele opleiding betrokke was. As student (in o.m. die Departement Afrikaans) wat self geskryf het, het ek mettertyd kennis gemaak met ' $n$ aantal medestudente wat my belangstelling in skeppende skryfwerk gedeel het. Vandag is heelparty van hulle, soos Johann de Lange, Johann de Waal, Harry Kalmer, André Letoit/Koos Kombuis, Victor Munnik, Fransi Phillips, Hans Pienaar en Koos Prinsloo (19571994), bekende skrywers. Deur persoonlike kontak en betrokkenheid by die Letterkundekring, en as redaksielid van sowel die tydskrif Vlieg as die studentekoerant Die Perdeby, is ek op verskillende maniere aan die ontwikkeling van die skryfvermoëns van hierdie talentvolle studente blootgestel. 
My betrokkenheid by opleiding in skeppende skryfwerk het gedurende 1984 begin toe ek met Charles Malan se goedkeuring en aanmoediging by die Sentrum vir Suid-Afrikaanse Letterkundenavorsing (SENSAL) van die Raad vir Geesteswetenskaplike Navorsing (RGN) aan die verslag Opleiding in skeppende skryfwerk in Suid-Afrika: 'n Sisteembeskrywing (1987) begin werk het. Een van die redes waarom ek die navorsing onderneem het, was om 'n bydrae te lewer tot 'n beter begrip en die bevordering van opleiding in skeppende skryfwerk in Suid-Afrika. Die gebrek aan opleiding in skeppende skryfwerk wat ek en ander jong skrywers ervaar het, het my laat besef dat daar 'n behoefte aan hierdie soort opleiding bestaan. Met die oog op hierdie navorsing het ek gedurende 1985 die Herfsskool vir Dramaturge en die eerste fase van die kursus in Afrikaanse prosaskryfkuns aan die Potchefstroomse Universiteit vir Christelike Hoër Onderwys (PU vir $\mathrm{CHO}$ ) bygewoon en dit geëvalueer. Alhoewel ek in daardie stadium nog net een digbundel, Die somer is ' $n$ dag oud (1983), gepubliseer het, was ek sedert 1981 redakteur van die poësietydskrif Ensovoort. Deur die tydskrif het ek kennis gemaak met ander skrywers wat graag wou weet of hulle oor skryftalent beskik en of hulle werk publiseerbaar is.

Teen die einde van 1985 het N.C. van Ryneveld, direkteur van die Instituut vir Voortgesette Opleiding (IVO) van UNISA, my gevra om gedurende 1986 'n werkswinkel vir roman- en kortverhaalskrywers aan te bied. Ek het ingewillig en dit het my vuurdoop in opleiding in skeppende skryfwerk geword. 1

In hierdie artikel word die opleiding in skeppende skryfwerk bespreek wat deur die IVO tussen 1985 en 1993 aangebied is, met besondere verwysing na my eie ervaring in die aanbied van sowel die roman- en

Sedertdien was ek ook by ander kursusse betrokke: gedurende die tweede semester van 1986 bied ek ná die vertrek van Lina Spies na die Universiteit van Stellenbosch die nie-formele letterkundewerkswinkel vir derdejaarstudente in die Departement Afrikaans van die Universiteit van Pretoria aan; gedurende Augustus 1987 bied ek by die Hoërskool Sasolburg 'n groepsessie aan by die skryfsimposium vir hoërskoolleerlinge uit die omliggende streek; ek bied werkswinkels aan by die Buitekurrikulêre Sentrum vir Hoogbegaafde Leerlinge aan die Pretoriase Onderwyskollege (1987, 1990 en 1992); en by die jaarvergadering van die Afrikaanse Skrywersgilde (1988); ek bied ' $n$ werkswinkel (1991) en 'n lesing (1993) vir digters by die ATKVskryiskool van die PU vir CHO aan; en gedurende 1994 en 1997 lewer ek gaslesings voor die honneursklas in skeppende skryfwerk (poësie) van die Universiteit van Pretoria.

Benewens die verslag van Marais (1987) is daar ook gedurende 1991 'n kontrakprojek, Die ontwerp en aanbieding van werkswinkels vir sknwersopleiding, deur die Stigting vir die Skeppende Kunste aan die RGN toegeken. As gevolg van die uiffasering van navorsing oor die kunste by die RGN is hierdie projek nie voltooi nie. 
kortverhaalkursus (1986-1992) as die poësiekursus (1993). Alhoewel die bespreking hoofsaaklik oor die roman- en kortverhaalkursus sal handel, sal ek ook na die poësiekursus verwys. Die klem val op eersgenoemde kursus omdat ek hierdie kursus die langste aangebied het. Die doel van die bespreking is om aan te toon watter faktore ' $n$ rol by die beplanning en aanbieding van die kursusse gespeel het. Die bespreking word egter nie aangebied as die "laaste woord" oor so 'n kursus nie. Daarvoor is opleiding in skeppende skryfwerk immers té dinamies en vloeibaar.

\section{Begin van die betrokkenheid}

Die IVO bied na-uurs by UNISA nie-formele verrykingskursusse oor ' $n$ verskeidenheid onderwerpe aan. In 1985 het die IVO begin met die eerste twee werkswinkels vir skrywers. Ridley Beeton, digter en akademikus verbonde aan die Departement Engels, wat kennis van sodanige werkswinkels in die Verenigde State van Amerika opgedoen het, het die inisiatief met die instelling van die skryfskool geneem. Albei werkswinkels is in Engels aangebied en het opleiding in die skryf van "poetry" en "expressive prose" behels.

Die kursusse was nie op beginners gerig nie en van voornemende kursusgangers is verwag om voorbeelde van hulle eie skryfwerk voor te lê. Albei werkswinkels het uit 15 sessies van twee uur elk bestaan. $\mathrm{Na}$ afloop van die poësiewerkswinkel het die IVO 'n publikasie, getiteld The poetry workshop of 1985 (1986), met gedigte deur kursusgangers en besprekings daarvan onder redakteurskap van Beeton uitgegee. 2

Op grond van die sukses van bogenoemde twee werkswinkels het die IVO in 1986 'n aantal nuwe werkswinkels ingestel, insluitende Afrikaanse kursusse in die skryf van:

- Poësie

- Roman en kortverhaal

- Televisiedraaiboek

- Prosa, poësie en drama vir hoërskoolleerlinge

2 In 'n brief van 12 Augustus 1988 aan die RGN na aanleiding van die publikasie van Marais se verslag (1987) skryf Ridley Beeton soos volg:

[...] the Poetry Workshops continued, as individual and group activities, and by correspondence through 1986, 1987 and 1988. The result (in published form) has been six monthly issues of POETRY WORKSHOPS, PRETORIA in 1987, the appearance of a second annual THE POETRY WORKSHOP OF 1987, and the appearance (some of the issues ahead of time) of a new monthly publication WRITERS' WORKSHOP, SOUTHERN AFRICA. I am also working on separate pamphlets on specific writers (including myself, under a pseudonym). 
Min belangstelling is in die kursusse vir hoërskoolleerlinge getoon en die (enkele) belangstellende leerlinge moes uiteindelik in die kursusse vir volwassenes geakkommodeer word. Daar was ook opvallend meer belangstelling in die roman- en kortverhaalkursus en die televisiedraaiboekkursus as die ander twee kursusse, waarskynlik omdat eersgenoemde kursusse as "broodwinnerskursusse" bestempel kan word.

Gedurende 1987 is addisionele kursusse in die skryf van kinder- en jeugliteratuur en radiohoorspele bygevoeg. Laasgenoemde is egter nog in dieselfde jaar afgeskaf as gevolg van 'n gebrek aan belangstelling. Die poësiekursus is van 1986 tot 1988 deur N.J. Snyman van die Departement Afrikaans en Nederlands van UNISA aangebied en van 1989 tot 1992 deur die digter Johann de Lange. Ná De Lange se verhuising na Kaapstad is die kursus in 1993 deur my aangebied, terwyl Renée Marais van die Departement Afrikaans van die Universiteit van Pretoria in dieselfde jaar die roman- en kortverhaalkursus aangebied het. (Sy het gedurende voorafgaande jare by geleentheid in sowel die roman- en kortverhaalkursus as die poësiekursus lesings waargeneem.) Die kursus in kinder- en jeugliteratuur is van 1987 tot 1990 deur Rina Thom van die SAUK aangebied.

Teen die einde van 1993 het die IVO besluit om nie met die skryfkursusse voort te gaan nie. Dié besluit kan waarskynlik toegeskryf word aan die toename in ander kursusse (veral kursusse in outogtone tale), wat tot probleme met die beskikbaarheid van lokale aanleiding gegee het. Aangesien die kursusgangers hoofsaaklik uit Pretoria en die onmiddellike omgewing gekom het, was daar ook mettertyd 'n effense afname in die aantal kursusgangers, wat waarskynlik ook tot die rasionalisasie bygedra het.

\section{Doel van die opleiding}

Die IVO voorsien in die behoefte aan nie-formele opleiding vir persone wat in 'n bepaalde onderwerp geïnteresseerd is, dikwels nie oor genoegsame akademiese kwalifikasies beskik om formele opleiding te kan ontvang nie en/of verkies om 'n kort kursus oor die onderwerp by te woon. Vir opleiding in skeppende skrytwerk het dit ook voorsien in die behoefte wat deur die gebrek aan sowel formele as nie-formele opleiding in en om Pretoria gelaat is.

Om die kursus vir roman- en kortverhaalskrywers bekend te stel, het ek in oorleg met die direkteur van die IVO 'n kort inskrywing vir die bekendstellingsbrosjure opgestel. Dit het soos volg gelui: 
Gedurende dié werksessies sal die algemene kenmerke van die subgenres omlyn word. Verder sal die werk van die verskillende deelnemers bestudeer en bespreek word en aandag gegee word aan die afronding en verhoging van die literêre vlak. Teen die einde van die kursus behoort elke kursusganger 'n roman/kortverhaal te hê wat persgereed sal wees en vir publikasie aan 'n uitgewer aangebied sal kan word.

Die doel van die kursus was dus om die kursusgangers in te lei in die kenmerke van die subgenres en die elemente van 'n narratiewe teks, en om deur die bespreking van hulle skryfwerk hulle oor die vereistes van uitgewers in te lig. Publiseerbaarheid was vir my die belangrikste kriterium vir die beoordeling van die gehalte van die kursusgangers se skryfwerk.

Die Jaarboek 1993 stel die poësiekursus soos volg bekend:

Die poësiekursus sal bestaan uit 'n bespreking van kreatiwiteit, tendense in die moderne poësie, poësietegnieke en manuskripversorging. Besondere aandag sal aan kursusgangers se eie skryfwerk gegee word.

Kursusgangers word versoek om drie gedigte by hulle inskrywings in te sluit.

My algemene benadering tot die aanbied van opleiding in skeppende skrytwerk wat in die roman- en kortverhaalkursus neerslag gevind het, is ook met die poësiekursus gevolg.

\section{Die ontwerp van 'n kursus in kreatiewe skryfkuns}

\section{- Die aanbieder(s) van so 'n kursus}

Die grootste uitdaging aan my as aanbieder van die roman- en kortverhaalkursus was om opleiding aan te bied in 'n genre wat ek nie self beoefen het nie. Ek kon dus nie staatmaak op eie ervaring en die outoriteit wat daarmee gepaard kan gaan nie. Die wysste benadering sou waarskynlik gewees het om die versoek om die kursus aan te bied van die hand te wys en om liewer iemand te nader wat wel die genre beoefen

My navorsing oor opleiding in skeppende skryfwerk was in 1986 egter reeds ver gevorder en een van die vrae waarmee ek geworstel het, was of iemand wat nie self skryf nie, of wat beperkte ervaring as skrywer het, of as skrywer ' $n$ ander genre beoefen, suksesvol as die aanbieder van opleiding in skeppende skryfwerk kan optree. Deur die aanbieding van die roman- en kortverhaalkursus kon ek dus uitsluitsel oor die saak kry. 
Ek sou egter moes meeding met die gevierde D.J. Opperman wat die Letterkundige Laboratorium van die Universiteit van Stellenbosch aangebied het, en die algemene opvatting dat hierdie soort opleiding in 'n gevestigde skrywer se hande gelaat moet word, die hoof moes bied. Hierdie enigsins eksklusiewe opvatting het waarskynlik daartoe bygedra dat opleiding in skeppende skryfwerk nie elders aangepak is nie

Tydens die ontwerp van die kursus vir roman- en kortverhaalskrywers het ek van die veronderstelling uitgegaan dat skeppende skryfwerk 'n studierigting is wat deur verskillende aanbieders oorgedra kan word. Alhoewel die opvatting bestaan dat 'n skrywer so 'n kursus behoort aan te bied, het alle skrywers byvoorbeeld nie die temperament om opleiding in skeppende skryfwerk aan te bied nie. Ideaal gesproke, behoort 'n aanbieder self ervaring van skeppende skrytwerk te hê, gepaardgaande met indringende kennis van die eienskappe van die genre waarin opleiding aangebied word en die temperament en vermoë om in 'n opleidingsituasie met skrywers te kan werk. ' $n$ Beduidende deel van die bespreking oor opleiding in skeppende skryfwerk word in beslag geneem deur die kwessie van wat aangebied kan word deur 'n dosent wat nie noodwendig self 'n skrywer is nie, maar in die aanbied van skeppende skryfwerk spesialiseer. In Afrikaans is daar tans meer as een voorbeeld van sodanige aanbieders.

Toe ek in 1993 besluit het om die poësiekursus aan te bied, moes ek behoorlik van genre verwissel. Een van die voordele van hierdie kursus was dat dit moontlik was om meer van die kursusgangers se tekste in die kursus te behandel. Die feit dat ek self poësie skryf, het groter geloofwaardigheid aan my rol as aanbieder gegee. Ek glo egter dat daar heelwat sake is wat nie genre-gebonde is nie en elke skrywer in 'n belangrike mate raak, onder meer kreatiwiteit, die rol van die uitgewer en die onderhandelingsproses met uitgewers en tydskrifte, en die resepsie van die skrywer se werk wat tydens elke kursus aandag behoort te kry. Om hierdie rede is dit moontlik dat ' $n$ aanbieder wat bereid is om hom/haar vir die eise van 'n bepaalde genre oop te stel wel as aanbieder van 'n kursus vir skrywers in daardie genre kan optree.

\section{- Kursusgangers en werksessies}

Die eerste byeenkoms het ek hoofsaaklik gebruik om die sowat vyftien kursusgangers te leer ken. Nadat ek myself voorgestel het, het elkeen van die kursusgangers die geleentheid gekry om hom- of haarself voor te stel en om iets oor hom- of haarself te sê. Ek het my dit van die begin af ten doel gestel om moeite te doen sodat ek en die kursusgangers mekaar kon leer ken. Om hierdie rede het ek ook voorgestel dat die 
klasse informeel moes wees, en het oud en jonk mekaar op die voorname aangespreek.

Dit was ook belangrik om uit te vind wat en waarom elkeen van die kursusgangers skryf. Hierdie deel van die gesprek het verskillende uitsprake opgelewer en daarop gedui dat die groep besonder heterogeen was - 'n verskynsel wat hom daarna herhaal het in elke kursus wat ek by die IVO aangebied het. Om vollediger inligting oor elke kursusganger te bekom, het ek elkeen 'n verkorte en aangepaste weergawe laat invul van die vraelys wat ek gedurende 1985 gebruik het om die eerste fase van die kursus in Afrikaanse prosaskryfkuns by die $\mathrm{PU}$ vir $\mathrm{CHO}$ te evalueer. Die oorspronklike vraelys is in Marais (1987:75-78) as Bylae B opgeneem.

Uit die ingevulde vraelyste kon ek inligting oor die kursusgangers se ouderdomme en beroepe kry - gegewens wat in ' $n$ heterogene groep nuttig is om 'n duideliker profiel van elkeen saam te stel. Hierbenewens kon ek vasstel in watter taal elkeen van hulle verkies om te skryf, wat en hoeveel hulle lees, of elkeen van die kursusgangers reeds eie skeppende skryfwerk gepubliseer het, of hulle voorheen opleiding in skeppende skryfwerk ontvang het, hoe hulle oor die waarde daarvan oordeel, en oor die aard van die leiding waaraan hulle met hulle skryfwerk die grootste behoefte het.

Die inligting wat ek uit die vraelyste bekom het, het 'n beduidende rol gespeel om my in staat te stel om 'n kursus te ontwerp wat aan die kursusgangers se behoeftes voldoen het. Ek het egter ook besluit om die kursusgangers meer te laat uitvind oor skeppende skryfwerk en letterkunde in die breë. Daarom het ek 'n kursus in gedagte gehad wat die kursusgangers 'n kyk in die wêreld van die skrywer en die letterkunde sou gee.

Aangesien die kursus in die vorm van 'n werkswinkel aangebied is en maksimum deelname van die kursusgangers aangemoedig is, het ek hulle die banke in ' $n$ kring laat rangskik. Sodoende is probeer om my rol as aanbieder te "relativeer" omdat ek dit as ideaal beskou het om 'n gespreksgenoot vir die kursusgangers te wees. Baie kursusgangers het inderdaad met die verwagting na die kursus gekom dat die aanbieder die spil sou wees waarom alles draai. Ek het dit gevolglik sterk beklemtoon dat die kursusgangers se deelname aan die besprekings en hulle interaksie met mekaar ' $n$ wesenlike deel van die kursus sou vorm. Die kursusgangers sou veral ook 'n belangrike rol speel as lesers vir mekaar en my rol as aanbieder sodoende beduidend aanvul. Deur die voorafgaande benadering te volg, het ek nie my verpligtinge probeer ontduik nie. Ek het immers my ervaring van verskeie aspekte van die skryf- 
ambag (en bekende skrywers) met die kursusgangers gedeel en hulle het graag geluister na wat ek te sê gehad het.

Tydens die eerste werksessie was dit nodig om opleiding in skeppende skryfwerk in perspektief te stel. Klem is daarop gelê dat talent nie tydens die kursus gekweek kan word nie, maar dat die kursus wel daartoe kan bydra om talent te slyp en om die kursusgangers met die hele kommunikasiesituasie waarin die skrywer hom/haar bevind, kennis te laat maak. Ek het ook aandag gegee aan die verskillende soorte opleiding wat vir skrywers beskikbaar is, soos keurdersverslae van tydskrifte en uitgewers, skrywershandleidings en individuele opleiding, en hoe elkeen aanvullend tot die huidige opleiding aangewend kan en behoort te word.

\section{- Inligting oor die skryfambag}

Aangesien werksessies al om die ander week aangebied is, was daar betreklik baie tyd om veral die prosa-opdragte tot hulle reg te laat kom, alhoewel nog meer tyd die kursusgangers selfs beter geleentheid sou gee om te ontwikkel. Dat kursusgangers klaarblyklik self hieraan behoefte gehad het, het geblyk uit die feit dat 'n hele aantal die kursus 'n tweede keer bygewoon het, in welke geval 'n gevorderde kursus naas die "gewone" kursus aangebied is

Aangesien die roman- en kortverhaalkursus aangebied is met die doel om nie-formele opleiding te verskaf aan aspirantskrywers wat veral in die skryf van goeie gewilde prosa en literêre verhale geïnteresseerd was, was dit belangrik om die kenmerke van hierdie soort tekste te behandel. Daarmee saam het ek ingegaan op die bou-elemente van die epiese werk om 'n grondslag vir 'n gesprek oor die struktuur van 'n prosateks te lê.

Benewens hierdie teoretiese inligting, wat op die skryfproses self afgestem was, is heelwat aandag gegee aan aspekte van die skryfambag self, met baie verwysings na ander skrywers en hulle werk. 'n Groot aantal kursusgangers het immers geen naskoolse opleiding in die letterkunde gehad nie en dit was 'n geleentheid om hulle op hierdie manier daarmee kennis te laat maak. Die meeste aandag is nietemin deurgaans aan die kursusgangers se eie werk gegee, spesifiek met die doel om hulle sover te bring om werk te lewer wat gepubliseer kon word.

Op die vraag hoeveel inligting oor die prosa ideaal gesproke in 'n kursus vir prosaskrywers aangebied behoort te word, het ek van die begin af nie 'n eenvoudige antwoord gehad nie. Dit geld ook vir ander genres; ook die poësie. Is dit byvoorbeeld nodig om tydens 'n prosakursus in 
skeppende skryfwerk die kursusgangers in die nuutste bevindings van die narratologie in te lei? In watter mate moet kursusgangers kennis maak met verhaalteoretiese bevindings en terminologie? 'n Bron soos Heilna du Plooy se Verhaalteorie in die twintigste eeu (1986) bied waarskynlik meer gespesialiseerde inligting as wat selfs vir nagraadse opleiding in skeppende skryfwerk nodig is, terwyl 'n bron soos J.P. Smuts se Hoe om 'n roman te ontleed (1984) waarskynlik voldoende inligting vir ' $n$ basiese, nie-formele kursus in verhalende tekste bied.

Daar is nie eenvoudige antwoorde op hierdie vrae nie. My benadering was nogtans deurgaans om nie 'n kursus in die Afrikaanse letterkunde of in literatuurwetenskap aan te bied nie. Leon Strydom (1983:99) het al tereg beweer dat "die skrywer en die literatuurwetenskaplike hulle in gans verskillende kommunikasie-situasies" bevind - 'n waarneming wat betekenisvolle implikasies vir opleiding in skeppende skryfwerk het. Kennis van die letterkunde of die literatuurwetenskap kan wel vir 'n skrywer nuttig wees, maar dit is nie 'n sleutel tot sukses nie. 'n Skrywer hoef daarom nie noodwendig 'n uitgebreide kennis van die teorie te hê nie. Te veel klem op teorie kan selfs inhiberend of ontmoedigend wees. As ' $n$ skrywer self belangstelling in die teorie het, kan daar vanselfsprekend nie beswaar teen ingebring word nie. Aan die ander kant sal 'n skrywer wat wyd lees, waarskynlik self deur sy/haar leeswerk met strominge soos die postmodernisme en tipes soos die metaroman kennis maak. Kursusgangers kan wel nuwe teorie geleer word, maar daar is geen rede waarom daar nie (veral in nie-formele opleiding) van die basiese teorie en maklik verstaanbare terminologie uit E.M. Foster se Aspects of the Novel (1979; eerste uitgawe 1927) gebruik gemaak kan word nie.

Die vraag sou verder gestel kon word of dit wenslik is om kursusgangers met uiteenlopende belangstellings saam in een kursus te akkommodeer. Moet/kan skrywers wat in die skryf van literêre verhale, dié wat meer in die skryf van goeie gewilde prosa en dié wat in die skryf van triviaalliteratuur geinteresseerd is, in dieselfde kursus geakkommodeer word? Daar sou gevra kon word of daar nie van die beginsel uitgegaan moet word om al die kursusgangers aan "goeie letterkunde" bloot te stel en hulle aan te moedig om werke met literêre verdienste te skryf nie.

Aangesien ek geen besondere soort prosa probeer bevorder het nie en kursusgangers die geleentheid wou bied om hulle eie belangstelling te ontwikkel, het ek probeer om die kenmerke van die verskillende soorte prosa aan te bied. Die teks wat die nuttigste in hierdie verband was, was Umberto Eco se The Role of the Rreader (1979). Daar is aangetoon dat daar oop en geslote tekste is, wat ook as ' $n$ betekenisvolle verskil tussen literêre en nie-literêre tekste beskou kan word. By geslote tekste is 
verwys na die speurverhaal, wat 'n onderskeibare struktuur vertoon en in eie reg 'n plek in die literatuur inneem. In die literêre sisteem wat enigsins elitistiese literêre maatstawwe navolg, het hierdie perspektief tot 'n demokratieser siening van literatuur bygedra. Heelwat wanopvattings oor die literêre en die gewilde werk kon op hierdie manier uit die weg geruim word en kursusgangers so die vrymoedigheid gee om self te besluit wat hulle graag wil skryf.

\section{- Leeslyste}

'n Aantal boeke is vir die kursusgangers voorgeskryf. Alhoewel enkele van die tekste redelik breedvoerig bespreek is, is hulle hoofsaaklik as voorbeelde in die kursus gebruik. Dit het besprekings van verhaalelemente, stylkenmerke, die wyse waarop dialoog aangebied word, ensovoorts ingesluit. Nog 'n rede vir die voorskryf van 'n leeslys was om die soms beperkte leeservaring van die kursusgangers aan te vul en om die wanopvatting dat 'n skrywer nie deur ander skrywers beïnvloed moet word nie, uit die weg te ruim.

Die tekste wat voorgeskryf is, het jaarliks gewissel. As handleiding het ek egter van die begin af Hennie Aucamp se Die blote storie (1986) gebruik. Hierdie "werkboek vir kortverhaalskrywers" het inderdaad in 'n groot behoefte voorsien en kursusgangers moes die boek lees en van die oefeninge doen. In die praktyk het dit egter geblyk dat die boek nie heeltemal geskik is vir die opleiding van skrywers wat nie in die literêre verhaal geïnteresseerd is en/of nie oor omvattende leeservaring beskik nie.

Verder is J.P. Smuts se blokboek Hoe om 'n roman te ontleed (1984) gebruik om die bou-elemente van die epiese werk te behandel. Vir die doeleindes van 'n nie-formele kursus was die hoeveelheid inligting in hierdie werk grootliks voldoende, alhoewel die terminologie en benadering enigsins verouderd en nie meer heeltemal toereikend is nie (kyk Marais, 1993:36-38). J.C. Kannemeyer se Prosakuns (s.j.) en T.T. Cloete, Elize Botha en Charles Malan se Gids by die literatuurstudie (1985) is ook by geleentheid met wisselende sukses gebruik.

Daar is elke keer 'n bloemlesing kortverhale voorgeskryf. My keuse het op óf Abraham H. de Vries (samest.) se Die Afrikaanse kortverhaalboek (1990) óf A.P. Grové (samest.) se Hoogtepunte in die Afrikaanse verhaalkuns (1985) geval; bloemlesings wat kursusgangers die geleentheid gebied het om met 'n groot verskeidenheid verhale kennis te maak. (Dit was opvallend dat veral J. van Melle se kortverhale boeiend "herskryfbaar" is.) 
Hierbenewens het ek die kursusgangers na 'n verskeidenheid kortverhaalbundels verwys, wat Hennie Aucamp se Dalk gaan niks verlore nie en ander tekste (1992), Abraham $\mathrm{H}$. de Vries se Nag van die clown (1989) en Fransi Phillips se Sewe \& sewentig stories oor 'n clown (1985) ingesluit het.

Ek het ook tydens sowel die roman- en kortverhaalkursus as die poësiekursus in die trant van W.H. Auden (in Scully, 1973:180) se "Daydream College for Bards" uit eie ervaring enkele praktiese hulpmiddels genoem wat vir die prosaskrywer en/of digter baie bruikbaar kan wees:

- 'n Goeie verklarende woordeboek, soos die HAT.

- 'n Goeie tweetalige woordeboek, soos dié van Bosman, Van der Merwe en Hiemstra (1984).

- Die nuwe Afrikaanse woordelys en spelreëls (1991) - sy 39 setfoute ten spyt.

- 'n Simboolwoordeboek.

- Louis Eksteen se Eensillabige rymwoordeboek van Afrikaans (1981) vir digters.

- Louis Eksteen se Afrikaanse sinoniemwoordeboek met antonieme (1984)

- 'n Goeie versameling Afrikaanse romans, kortverhale en digbundels.

- 'n Goeie versameling romans, kortverhale en digbundels in ander tale.

Hierbenewens het ek die belang van die volgende ook benadruk:

- 'n Plek om gereeld by te kan skryf.

- 'n Rekenaar, as 'n kursusganger een kan bekostig. Dit is egter deesdae glad nie meer 'n luukse nie - trouens, die meeste skrywers werk op een. Dit vergemaklik die versorging van 'n teks en/of manuskrip in 'n groot mate en dit help die skrywer om afstand van sy/haar teks te verkry. Deur van elektroniese woordeboeke en spelkontroles gebruik te maak, kan heelwat tyd ook bespaar word.

\section{- Beïnvloeding en plagiaat}

Ek het ook op die belangrikheid van lees klem gelê. Dit het ek gemotiveer aan die hand van die rol wat intertekstualiteit tans in die letterkunde speel. Ek het die standpunt gestel dat indien daar so baie "beïnvloeding" in die letterkunde aangetoon kan word dat daar selfs beweer word dat geen teks in isolasie kan bestaan nie en altyd die spore van ander tekste vertoon, is die logiese afleiding wat gemaak kan word 
dat 'n skrywer hom/haar juis moet laat beïnvloed. 'n Skrywer moet leeswerk benut om te sien wat hy/sy by ander skrywers kan leer en om vas te stel wat deur sy/haar tydgenote geskryf word. Dit impliseer dat elke skrywer by implikasie deurgaans in gesprek met ander tekste is. (Hierdie tekste sluit sekerlik ook nie-literêre tekste in.)

$\mathrm{Na}$ aanleiding van bogenoemde het daar byna altyd 'n gesprek oor plagiaat gevolg. Is dit dan geoorloof? Moet 'n skrywer beïnvloed word? Dit het geblyk dat aspirantskrywers bang is om deur ander skrywers beïnvloed te word en daarom selfs daarvan wegskram om baie te lees. Ek het telkens beklemtoon dat dit nié beteken dat die skrywer plagiaat mag pleeg of ander skrywers kritiekloos moet naboots nie. 'n Skrywer moet te midde van die stemme van ander skrywers sy/haar eie stem ontdek en daarom het ek dit deurgaans beklemtoon dat selfontdekking 'n belangrike voorwaarde vir suksesvolle skrywerskap is. Die skrywer moet juis sy/haar uniekheid in die skryfwerk na vore laat kom.

\section{- Skryfopdragte}

Binne hierdie konteks het ek die kursusgangers laat skryf. In die prosakursus het ek die volgende skryfopdragte gegee:

- 'n Essay: Nadat die kenmerke van die essay behandel is, is kursusgangers voorbeelde van die essay laat lees en essayiste soos M.E.R., N.P. van Wyk Louw, Marthinus Versfeld, Audrey Blignault en Gerrit Olivier se werk bespreek, en moes elkeen 'n essay skryf. Die skryf van 'n essay is as 'n toets beskou vir die vermoë om prosa te skryf en by monde van Van Wyk Louw (1973:11) is beklemtoon: "[O]m te kan skryf, moet 'n mens taal goed ken."

- 'n Vertaling. Die rol van vertaling in die letterkunde is bespreek. Aucamp (1986:11) wys daarop dat "studentevertalings van kortverhale uit die wêreldletterkunde die ruggraat van [sy] kursus geword" het. Veral Bessie Head se verhaal "Looking for a Rain God" uit die bundel The Collector of Treasures and Other Botswana Village Tales (1977) is gebruik.

- 'n Kortkortverhaal: Ons het die kenmerke van die kortkortverhaal (kyk Lombard, 1979) bespreek en of dit wenslik is om dit as 'n subgenre te onderskei. Tekste van skrywers soos Breyten Breytenbach, John Miles, P.J. Haasbroek en Johan van Wyk is bespreek en daarna is kursusgangers opdrag gegee om 'n teks van tussen 300 en 1500 woorde - na aanleiding van die lengtebepaling van die kortkortverhaal in Gouws en Roodt (1990:239) - te skryf. 
- 'n Kortverhaal: Die meeste besprekingsessies tydens die kursus is aan die kortverhaal gewy. Daar is deurgaans na die werk van sowel Afrikaanse as buitelandse skrywers verwys en kursusgangers is aangemoedig om hulle werk te lees. Die opdrag was om 'n kortverhaal van ongeveer agt tot tien bladsye met die oog op publikasie in een of ander tydskrif te skryf.

Die temas waaroor kursusgangers kon skryf, was nooit onbuigsaam nie. Dit het nietemin geblyk dat hulle ' $n$ opdrag om oor 'n bepaalde onderwerp te skryf, stimulerend gevind het. Daarom het ek navorsing vir die skryf van 'n verhaal aangemoedig en skrywers (bv. Dalene Matthee en Karel Schoeman) genoem wat baie moeite in dié opsig doen. 'n Aanbieder moet egter aanpasbaar wees en nie 'n kursusganger kwalik neem of penaliseer indien hy/sy nie by die oorspronklike opdrag gehou het nie, maar iets anders geskryf het. Dit was nietemin belangrik om seker te maak dat kursusgangers wel nuwe werk vir beoordeling voorlê en nie net bestaande tekste inlewer nie. Daarenteen lyk dit vir my ook belangrik om kursusgangers nie te dwing om te skryf indien hulle om een of ander rede nie sover kom om te skryf nie. So 'n "onvermoë" of "onwilligheid" om te skryf, dui nie noodwendig daarop dat die kursusganger glad nie in staat is om te skryf nie.

\section{- Evaluering van kursusgangers se werk}

Die evaluering van kursusgangers se werk bied een van die grootste uitdagings aan die aanbieder van opleiding in skeppende skrytwerk. Ten eerste moet aanvaar word dat 'n aanbieder daartoe in staat moet wees om 'n ewewigtige waardeoordeel oor 'n aspirantskrywer se werk te kan maak en dat hy/sy sal weet hoe om dit op die beste en mees diplomatiese wyse aan die kursusganger oor te dra. Tweedens moet die aanbieder ook in staat wees om nie net 'n waardeoordeel oor 'n teks uit te spreek nie, maar ook voorstelle ter verbetering van die teks aan die hand te doen en die skrywer te lei om die teks te verbeter. Aangesien 'n groot verskeidenheid tekste voorgelê kan word, kan hierdie faset groot eise aan die aanbieder stel. Dit is ook ' $n$ rede waarom die aantal kursusgangers wat die kursus bywoon, beperk behoort te word.

In die kursus is van ' $n$ puntestelsel gebruik gemaak waarvolgens die publiseerbaarheid van ' $n$ teks as die belangrikste norm beskou is. By die lees van ' $n$ teks het ek my daarom telkens afgevra of die teks publiseerbaar is. Is daar een of ander tydskrif of uitgewer wat daarin sal belangstel om die teks te publiseer? Aan 'n teks wat aan hierdie kriterium voldoen, is 80 persent of meer toegeken. In die geval van korter tekste is verkies om 'n punt uit 10 te gee. Verder het ek selde minder as 50 persent toegeken, aangesien ek nie graag die kursusgangers wou 
ontmoedig nie. As 'n kursusganger nogtans voortgegaan het om bepaalde foute en hebbelikhede te herhaal, het ek hom/haar wel met 'n punt laer as 50 persent gepenaliseer. Ek het elke jaar die kriterium waarvolgens ek punte toegeken het, uitvoerig met die kursusgangers bespreek.

'n Verdere vorm van evaluering wat in die kursus toegepas is, was die bydrae wat kursusgangers gelewer het om mekaar se werk te lees en te bespreek. In die mate waarin dit prakties moontlik was, is kursusgangers ook by die evaluering van mede-kursusgangers se tekste betrek. Met die oog hierop is van kursusgangers verwag om kopieë van die korter tekste soos die essays en kortkortverhale vir elke kursusganger te bring. Hierdie tekste is nie anoniem bespreek nie, aangesien ek van die standpunt uitgaan dat skrywers so gou moontlik blootgestel moet word aan werklike lesers, wat weet wie die skrywer van 'n teks is. My ervaring was dat hierdie benadering slegs in enkele gevalle in ' $n$ mate tot ' $n$ gevoel van gekwetstheid en ongemaklikheid gelei het.

\section{- Uitgewers en die voorbereiding van 'n manuskrip}

In die kursus is die rol van die skrywer binne 'n groter kommunikasiekonteks deurgaans aangedui. Daarom is daar baie aandag gegee aan die rol van die uitgewer en watter verwagtings uitgewers van skrywers koester. Gesprek is ook gevoer oor die onderhandelingsproses met uitgewers en tydskrifte. Dit het deurgaans geblyk dat kursusgangers onseker hieroor is en ek het talle wanopvattings uit die weg geruim. Heelwat klem is ook op die voorbereiding van 'n manuskrip met die oog op voorlegging aan 'n uitgewer gegee, en kursusgangers is aangemoedig om tydens die kursus die skryfopdragte op die manier voor te berei wat deur uitgewers verkies word. Hierbenewens is inligting gegee oor die versorging van proewe, die boek as artefak en die ontwerp en versorging van die boek as geheel, en aan bemarking.

\section{Geskakeerdheid van kursusgroepe}

Een van die kenmerke van nie-formele opleiding in skeppende skryfwerk is die geskakeerdheid van die kursusgroep. Dit geld op bykans alle vlakke: ouderdom, beroep, skryf-, lees- en vorige ervaring van opleiding in skeppende skryfwerk.

Sowel die roman- en kortverhaalkursus as die poësiekursus is bygewoon deur persone van uiteenlopende ouderdomme en beroepe, wat meegebring het dat ' $n$ mens deurgaans daarop bedag moes wees om die verskillende behoeftes in aanmerking te neem. Dit is opvallend dat 
daar jaarliks talle "ouer" persone vir die kursus ingeskryf het. Dit bevestig Kobus Neethling (1994:14) se uitspraak dat

[...] ouderdom nie 'n dominante faktor is nie en dat baie mense byvoorbeeld eers bo die ouderdom van 50 kreatiewe deurbrake maak. Faktore wat wel kreatiewe prestasies op hoë ouderdom meer uitdagend maak, is ' $n$ afname in fisiese energie, gesondheidsprobleme, sosiale en maatskaplike aanpassings en 'n vrees om 'n nuwe laaste lewensfase te betree.

Die voordeel van die teenwoordigheid van ouer persone was hulle belesenheid, iets wat dikwels by jonger lede van die groep ontbreek het. Die ouer persone se deelname aan gesprekke oor bepaalde skrywers en boeke het dan ook jonger aspirantskrywers aangemoedig om daardie boeke te gaan lees. Daarbenewens het die ouer persone dikwels oor lewenservaring beskik wat by ander kursusgangers ontbreek het.

Die behoefte aan opleiding in skeppende skryfwerk by 'n heterogene groep persone bevestig die belangrikheid van nie-formele opleiding. Kursusgangers wat die kursusse by die IVO bygewoon het en wie se werk later gepubliseer is, sluit in Hannah Bell, Elwin Buchel, Carol Coetzee, Sarina Dönges, Mione du Toit, Naas Ferreira, Eben Germishuys, Melanie Grobler, Elsa Hagelskamp, Paula Maud, Theresa Papenfus, Marietjie van der Walt, Amerie van Straaten en Johan van Zyl.

\section{Samevatting}

Die belangrikste gevolgtrekking waartoe ek tydens die aanbied van sowel die roman- en kortverhaalkursus as die poësiekursus gekom het, is dat die aanbieder van so ' $n$ kursus besonder aanpasbaar moet wees. Die aanbieder moet in staat wees om aan die kursusgangers leiding oor 'n wye verskeidenheid onderwerpe te gee en om gesaghebbend oor die letterkunde te praat. Dit is ook belangrik om kursusgangers op die belangrikste tendense in die hedendaagse letterkunde bedag te maak en om hulle sensitief te maak vir alles wat die skrywer kan help om publiseerbare werk te lewer.

Of opleiding in skeppende skryfwerk aangebied behoort te word, is eintlik nie meer ter sprake nie. Die talle opleidingskursusse wat aangebied word en die aanvraag wat daarvoor bestaan, is waarskynlik afdoende bewys van die behoefte waarin dit voorsien. Om die waarde van opleiding in skeppende skryfwerk betroubaar te evalueer, is egter nie sonder probleme nie. 'n Mens sou dit byvoorbeeld kon meet aan die hoeveelheid publikasies wat kursusgangers en voormalige kursusgangers die lig laat sien. Om sodanige publikasies nogtans sonder meer aan die insette van opleidingskursusse toe te skryf, lyk effens on- 
nadenkend. ${ }^{3}$ Die mate waarin 'n opleidingskursus vir die sukses van 'n skrywer deurslaggewend is, is ook moeilik meetbaar. Talle groot skrywers in die wêreldletterkunde én in die Afrikaanse letterkunde het sukses behaal nadat hulle (oënskynlik) hoogstens tot informele opleiding toegang gehad het.

Die geleentheid om tussen 1986 en 1993 by opleiding in skeppende skryfwerk by die IVO betrokke te kon wees, was vir my as skrywer én as navorser 'n besonder verrykende ervaring. Dit was 'n geleentheid wat ek nie sou wou misloop nie.

\section{Bibliografie}

Aucamp, Hennie. 1986. Die blote storie: 'n Werkboek vir kortverhaalskrywers Kaapstad : Tafelberg.

Aucamp, Hennie. 1992. Dalk gaan niks verlore nie en ander tekste. Kaapstad Tafelberg.

Beeton, Ridley. (ed.) 1986. The poetry workshop of 1985. Pretoria : UNISA

Bosman, D.B., Van der Merwe, I.W. \& Hiemstra, L.W. 1984. Tweetalige Woordeboek Bilingual Dictionary. Agtste, hersiene en vermeerderde uitgawe. Kaapstad Tafelberg.

Cloete, T. T., Botha, Elize \& Malan, Charles. (reds) 1985. Gids by die literatuurstudie Pretoria : HAUM-Literêr. HAUM-Literêr-Gidsreeks nr. 1.

De Vries, Abraham H. 1989. Nag van die clown. Kaapstad \& Pretoria : Human \& Rousseau.

De Vries, Abraham H. (samest.) 1990. Die Afrikaanse kortverhaalboek. Derde, hersiene uitgawe. Kaapstad \& Pretoria : Human \& Rousseau.

Du Plooy, Heilna. 1986. Verhaalteorie in die twintigste eeu. Durban : Butterworth.

Eco, Umberto. 1979. The Role of the Reader: Explorations in the semiotics of texts London : Hutchinson.

Eksteen, Louis. 1984. Afrikaanse sinoniemwoordeboek met antonieme. Tweede uitgawe. Pretoria : Van Schaik.

Eksteen, L.C. 1981. Eensillabige rymwoordeboek van Afrikaans. Johannesburg : Lex Patria.

Foster, E.M. 1979. Aspects of the Novel. London \& New York: Methuen. (First published in 1927.)

Gouws, Tom \& Roodt, P.H. (samests.) 1990 Kort-kort: 75 ongebundelde kortkortverhale. Pretoria : Van der Walt.

Grové, A.P. (samest.) 1985. Hoogtepunte in die Afrikaanse verhaalkuns. Sesde uitgawe, eerste druk. Kaapstad: Tafelberg.

Head, Bessie. 1977. The Collector of Treasures and Oother Botswana Village Tales. Cape Town : David Philip.

Instituut Vir Voortgesette Opleiding. 1993. Jaarboek. Pretoria : UNISA

Kannemeyer, J.C. s.j. Prosakuns. Kaapstad : NASOU.

3 Aan wie moet die sukses toegeskryf word indien ' $n$ kursusganger meer as een kursus bywoon? 
Lombard, Jean. 1979. Die kort-kortverhaal in Afrikaans. Stellenbosch : Universiteit van Stellenbosch. (M.A.-verhandeling.)

Louw, N.P. van Wyk. 1973. Vernuwing in die prosa: Grepe uit ons Afrikaanse envaring. Derde uitgawe, tweede druk. Pretoria \& Kaapstad: Academica.

Marais, Johann Lodewyk. 1983. Die somer is 'n dag oud. Kaapstad, Pretoria \& Johannesburg: Human \& Rousseau.

Marais, Johann Lodewyk. 1987. Opleiding in skeppende skrytwerk in Suid-Afrika: 'n Sisteembeskrywing. Pretoria : RGN. SENSAL-publikasie nr. 22

Marais, Renée. 1993. Aspekte van ruimte in Karel Schoeman se roman 'n Ander land. Pretoria : Universiteit van Pretoria. (M.A.-verhandeling.)

Neethling, Kobus. 1994. Kreatiwiteit laat jou wondere verrig. Sewende druk. Pretoria : Benedic

Odendal, F.F. et al. 1983. Verklarende Handwoordeboek van die Afrikaanse Taal. Tweede uitgawe, derde druk. Johannesburg: Perskor.

Phillips, Fransi. 1985. Sewe \& sewentig stories oor 'n clown. Pretoria : HAUM-Literêr.

Scully, James. (ed.). 1973. Modern Poets on Modern Poetry. London \& Glasgow : Fontana/Collins. (First published in 1966.)

Smuts, J.P. 1984. Hoe om 'n roman te ontleed. Tweede uitgawe, derde druk. Pretoria \& Kaapstad: Academica.

Strydom, Leon. 1983. Die jong skrywer: Die literatuur dienswillig. Klasgids, 18(1): 9699, Febr.

Suid-Afrikaanse Akademie vir Wetenskap en Kuns 1991. Afrikaanse woordelys en spelreë/s. Kaapstad : Tafelberg.

\section{Kernbegrippe:}

Afrikaanse poësie

Afrikaanse prosa

nie-formele opleiding

opleiding vir volwassenes

skeppende skryfwerk

skryfkuns-opleiding

\section{Key concepts:}

adult education

Afrikaans poetry

Afrikaans prose

creative writing

non-formal training

teaching creative writing 
